\begin{tabular}{|l|l|l|l|l|l}
\hline Int.J.Curr.Microbiol.App.Sci (2018) 7(10): 1427-1434 \\
$\begin{array}{l}\text { International Journal of Current Microbiology and Applied Sciences } \\
\text { ISSN: 2319-7706 Volume 7 Number 10 (2018) } \\
\text { Journal homepage: http://www.ijcmas.com }\end{array}$ \\
\hline $\begin{array}{l}\text { EXCELLENT } \\
\text { PUBLISHERS }\end{array}$
\end{tabular}

Original Research Article

https://doi.org/10.20546/ijcmas.2018.710.158

\title{
Studies on Storage Behaviour of Bitter Gourd as Influenced by Liquid Organic Manures
}

\author{
Somashekar Gajjela*, Ranjit Chatterjee, Sushmita Subba and Eggadi Ramesh \\ Department of Vegetable and Spice Crops, Faculty of Horticulture, Uttar Banga Krishi \\ Viswavidyalaya, Pundibari, Cooch Behar, West Bengal, India \\ *Corresponding author
}

\begin{abstract}
A B S T R A C T
Keywords

Bitter gourd, Shelf life, Physiological loss in weight (PLW), Organic amendments

Article Info

Accepted:

12 September 2018 Available Online: 10 October 2018

The influence of liquid organic amendments on bitter gourd was investigated to determine their effect on storage behaviour. Bitter gourd was raised in field by 48 treatment combinations comprising of different varieties and liquid organic manures at different levels. The results revealed that shelf life and physiological loss in weight of bitter gourd were significantly influenced by liquid organic manures and the better selection of variety and nutrient combination can eventually reduce the post-harvest physiological loss in weight (PLW) and increase the shelf life. The treatment combination Gangajal-1, three sprays of each panchagavya $3 \%$ at 20, 40 and 60 DAS and vermiwash $10 \%$ at 25, 50 and 75 DAS emerged as best in increasing the shelf life; and the treatment combination Pundibari Local, panchagavya $3 \%$ at 30 and 60 DAS, vermiwash $10 \%$ at 25,50 and 75 DAS emerged as best in decreasing the physiological loss in weight after 4 and 6 days of storage at room temperature.
\end{abstract}

\section{Introduction}

Bitter gourd (Momordica charantia L.) is the most widely cultivated cucurbit for its minerals and vitamins. It is a monoecious, viny, annual climber, cultivated in tropical and sub-tropical areas during summer and rainy season. It has been used as a traditional medicine for diabetes (e.g., India, China, and Central America; Grover et al., 2002; Yeh et al., 2003) and other health-related ailments e.g., health promoting substances such as charantin (Yeh et al., 2003) and vicine (Dutta et al., 1981). Today's crop production involves utilization of chemical fertilizers, pesticides and growth regulators for enhancing crop production. But, over dependence on chemical fertilizers adversely affects the soil and environment and also on humans (Subbarao et al., 2007). In recent days, liquid organic manures are getting relevance in organic cultivation. Foliar application of liquid organic manures absorbs nutrients 20 times faster than the applied through the soil. Temporary nutrient deficiencies can be overcome by using liquid organic manures. Whenever the nutrient uptake through the roots is stopped it stimulates growth by foliar application (Smoleń, 2012). Panchagavya is a fermented liquid made by blending five ingredients obtained from cow, such as milk, urine, dung, curd and clarified butter. 
Vermiwash is another liquid organic manure that is collected after the passage of water through a column of worm action. But, the studies on liquid organic manures in bitter gourd cultivation and its storage aspects is very meager in terai zone of West Bengal. The present research was undertaken to determine the best liquid organic manure combination for better storage of bitter gourd.

\section{Materials and Methods}

The experiment was conducted at UBKV, Pundibari, Cooch Behar, West Bengal, India $\left(26^{\circ} 19^{\prime} 86^{\prime \prime} \mathrm{N}\right.$ latitude and $89^{\circ} 23^{\prime} 53^{\prime \prime}$ E longitude) during 2016 and 2017. Bitter gourd was raised during spring summer season (February to May) in both the years. This experiment consists of three factors viz., three varieties $\left(\mathrm{V}_{1^{-}}\right.$Peyarafuli Ucche, $\mathrm{V}_{2^{-}}$Pundibari Local and $\mathrm{V}_{3}$ - Gangajal-1), four panchagavya (3\%) sprays $\left(\mathrm{P}_{0}-\right.$ no spray (control, water spray), $\mathrm{P}_{1}-$ one spray at $45 \mathrm{DAS}, \mathrm{P}_{2}-$ two sprays at 30 and $60 \mathrm{DAS}$ and $\mathrm{P}_{3}$ - three sprays at 20,40 and 60 DAS) and four vermiwash (10\%) sprays $\left(\mathrm{W}_{0^{-}}\right.$no spray (control, water spray), $\mathrm{W}_{1-}$ one spray at $35 \mathrm{DAS}, \mathrm{W}_{2}-$ two sprays at 25 and 50 DAS and $\mathrm{W}_{3}-$ three sprays at 25, 50 and 75 DAS).

Thus the experiment was laid out in three factor factorial randomized block design with 48 treatment combinations and replicated thrice. The seeds were sown in $4.5 \mathrm{~m} \mathrm{x} 1.2 \mathrm{~m}$ plots with the spacing of $1.5 \mathrm{~m} \times 0.6 \mathrm{~m}$. Azotobacter $(5 \mathrm{~kg})$ enriched farmyard manure (20 t/ha) as basal along with top dressing of vermicompost ( $5 \mathrm{t} / \mathrm{ha}$ ) at 30 days after sowing. $3 \%$ panchagavya was prepared by mixing 30 $\mathrm{ml}$ panchagavya in 1 lit of water or $300 \mathrm{ml}$ panchagavya in 10 lit of water. $10 \%$ vermiwash was prepared by dissolving $100 \mathrm{ml}$ of vermiwash in 1 lit of water or $1000 \mathrm{ml}$ vermiwash in 10 lit of water. The crop was raised by following the recommended cultural practices. To find the shelf life and physiological loss in weight five freshly harvested fruits for each treatment in each replication were taken randomly and kept at ambient conditions with proper ventilation. The average room temperature and relative humidity were $22^{\circ} \mathrm{C}$ and $80 \%$ respectively. The shelf life was measured in days when the 10 to $15 \%$ of the stored fruits become unfit for consumption. The physiological loss in weight was measured by subtracting initial weight from final weight and expressed in percentage. The storage data collected from the experiment was statistically analyzed using factorial randomized block design. Two years data were pooled and the results were subjected to analysis of variance. For determination of critical difference at 5\% level of significance (Fisher and Yates, 1963) table was consulted. The observations recorded from different treatments in the field as well as in the laboratory were subjected to statistical analysis by adopting the method suggested by Panse and Sukhatme (1985).

\section{Results and Discussion}

The results revealed that the shelf life of bitter gourd (Table 1 and 1a) increased significantly by use of different liquid organic manures. The shelf life was significantly influenced by different sprays of panchagavya. The maximum shelf life (3.97 days and 5.11 days in 2016 and 2017, respectively and 4.54 days in pooled analysis) of bitter gourd was recorded in $\mathrm{P}_{3}$ treatment (panchagavya $3 \%$ at 20, 40 and 60 DAS). The minimum shelf life (2.89 days and 4.06 days in 2016 and 2017, respectively and 3.47 days in pooled analysis) was recorded in $\mathrm{P}_{0}$ treatment (control, water spray). Similar observation was recorded earlier by Rajasree et al., (2004) in bitter gourd, Beaulah et al., (2001) in moringa. The effect of vermiwash on shelf life of bitter gourd was found to be significant in the year 2016 and in pooled analysis and nonsignificant in the year 2017. 
Int.J.Curr.Microbiol.App.Sci (2018) 7(10): 1427-1434

Table.1 Post-harvest parameters as influenced by variety, panchagavya and vermiwash and their interaction in bitter gourd

\begin{tabular}{|c|c|c|c|c|c|c|}
\hline & \multicolumn{3}{|c|}{ Shelf life (days) } & \multicolumn{3}{|c|}{ Physiological loss in weight (\%) poolec } \\
\hline & 2016 & 2017 & Pooled & 2 days & 4 days & 6 days \\
\hline \multicolumn{7}{|l|}{ Varieties (V) } \\
\hline $\mathbf{V}_{1}$ & 2.58 & 3.81 & 3.19 & 13.97 & 27.28 & 46.29 \\
\hline $\mathbf{V}_{2}$ & 3.85 & 5.22 & 4.54 & 11.88 & 24.65 & 47.26 \\
\hline $\mathbf{V}_{3}$ & 3.70 & 4.75 & 4.22 & 12.08 & 28.89 & 51.40 \\
\hline S. Em $( \pm)$ & 0.05 & 0.08 & 0.04 & 0.06 & 0.08 & 0.14 \\
\hline $\mathrm{CD}(\mathrm{P}=0.05)$ & 0.13 & 0.21 & 0.12 & 0.16 & 0.23 & 0.40 \\
\hline \multicolumn{7}{|l|}{ Panchagavya (P) } \\
\hline $\mathbf{P}_{0}$ & 2.89 & 4.06 & 3.47 & 18.68 & 39.99 & 67.93 \\
\hline $\mathbf{P}_{1}$ & 3.08 & 4.31 & 3.69 & 13.77 & 29.29 & 51.81 \\
\hline $\mathbf{P}_{2}$ & 3.58 & 4.92 & 4.25 & 7.85 & 16.23 & 30.57 \\
\hline $\mathbf{P}_{3}$ & 3.97 & 5.11 & 4.54 & 10.27 & 22.25 & 42.96 \\
\hline S. Em $( \pm)$ & 0.05 & 0.09 & 0.07 & 0.07 & 0.10 & 0.17 \\
\hline $\mathrm{CD}(\mathrm{P}=0.05)$ & 0.15 & 0.25 & 0.18 & 0.19 & 0.27 & 0.46 \\
\hline \multicolumn{7}{|l|}{ Vermiwash (W) } \\
\hline $\mathrm{W}_{0}$ & 3.22 & 4.44 & 3.83 & 14.80 & 30.36 & 55.35 \\
\hline$W_{1}$ & 3.28 & 4.56 & 3.92 & 13.28 & 28.00 & 49.01 \\
\hline $\mathrm{W}_{2}$ & 3.44 & 4.64 & 4.04 & 11.66 & 25.67 & 46.12 \\
\hline $\mathbf{W}_{3}$ & 3.58 & 4.75 & 4.17 & 10.83 & 23.74 & 42.79 \\
\hline S. $\operatorname{Em}( \pm)$ & 0.05 & 0.09 & 0.07 & 0.07 & 0.10 & 0.17 \\
\hline $\mathrm{CD}(\mathrm{P}=0.05)$ & 0.15 & NS & 0.18 & 0.19 & 0.27 & 0.46 \\
\hline \multicolumn{7}{|l|}{ V X P X W } \\
\hline $\mathbf{V}_{1} \mathbf{P}_{0} \mathbf{W}_{0}$ & 1.00 & 2.00 & 1.50 & 32.94 & 47.73 & 76.67 \\
\hline $\mathbf{V}_{1} \mathbf{P}_{\mathbf{0}} \mathbf{W}_{1}$ & 1.67 & 2.33 & 2.00 & 22.97 & 44.62 & 62.03 \\
\hline $\mathbf{V}_{1} \mathbf{P}_{0} \mathbf{W}_{2}$ & 2.00 & 2.33 & 2.17 & 17.29 & 38.75 & 60.12 \\
\hline $\mathbf{V}_{1} \mathbf{P}_{0} \mathbf{W}_{3}$ & 2.00 & 2.33 & 2.17 & 17.11 & 34.95 & 59.08 \\
\hline $\mathbf{V}_{\mathbf{1}} \mathbf{P}_{\mathbf{1}} \mathbf{W}_{\mathbf{0}}$ & 3.00 & 4.33 & 3.67 & 16.36 & 34.31 & 58.06 \\
\hline $\mathbf{V}_{\mathbf{1}} \mathbf{P}_{\mathbf{1}} \mathbf{W}_{\mathbf{1}}$ & 3.00 & 4.33 & 3.67 & 15.79 & 33.14 & 55.94 \\
\hline $\mathbf{V}_{1} \mathbf{P}_{1} \mathbf{W}_{2}$ & 3.00 & 4.33 & 3.67 & 15.12 & 28.39 & 51.49 \\
\hline $\mathbf{V}_{1} \mathbf{P}_{1} \mathbf{W}_{3}$ & 3.00 & 4.67 & 3.84 & 12.66 & 26.96 & 49.64 \\
\hline $\mathbf{V}_{\mathbf{1}} \mathbf{P}_{\mathbf{2}} \mathbf{W}_{\mathbf{0}}$ & 3.33 & 4.67 & 4.00 & 9.08 & 16.87 & 30.87 \\
\hline $\mathbf{V}_{1} \mathbf{P}_{2} \mathbf{W}_{1}$ & 3.33 & 5.00 & 4.17 & 8.92 & 16.12 & 29.37 \\
\hline $\mathbf{V}_{1} \mathbf{P}_{2} \mathbf{W}_{2}$ & 2.33 & 4.00 & 3.17 & 6.97 & 15.90 & 28.37 \\
\hline $\mathbf{V}_{1} \mathbf{P}_{2} \mathbf{W}_{3}$ & 2.67 & 4.00 & 3.34 & 6.50 & 13.21 & 22.22 \\
\hline $\mathbf{V}_{1} \mathbf{P}_{3} \mathbf{W}_{0}$ & 2.67 & 4.00 & 3.34 & 12.01 & 25.70 & 46.93 \\
\hline $\mathbf{V}_{1} \mathbf{P}_{3} \mathbf{W}_{1}$ & 2.67 & 4.00 & 3.34 & 11.01 & 21.36 & 39.50 \\
\hline $\mathbf{V}_{1} \mathbf{P}_{3} \mathbf{W}_{2}$ & 2.67 & 4.33 & 3.50 & 9.54 & 20.41 & 36.65 \\
\hline $\mathbf{V}_{\mathbf{1}} \mathbf{P}_{\mathbf{3}} \mathbf{W}_{\mathbf{3}}$ & 3.00 & 4.33 & 3.67 & 9.31 & 18.15 & 33.80 \\
\hline $\mathbf{V}_{2} P_{0} W_{0}$ & 3.00 & 4.33 & 3.67 & 19.61 & 43.31 & 84.80 \\
\hline $\mathbf{V}_{2} \mathbf{P}_{0} \mathbf{W}_{1}$ & 3.00 & 4.33 & 3.67 & 18.52 & 36.18 & 70.30 \\
\hline $\mathbf{V}_{2} \mathbf{P}_{0} \mathbf{W}_{2}$ & 3.00 & 4.33 & 3.67 & 16.18 & 33.51 & 63.40 \\
\hline $\mathrm{V}_{2} \mathrm{P}_{0} \mathrm{~W}_{3}$ & 3.00 & 4.33 & 3.67 & 15.27 & 31.04 & 58.12 \\
\hline
\end{tabular}

*Treatment details are in materials and methods 
Table.1a Interaction effect of variety, panchagavya and vermiwash on post-harvest parameters in bitter gourd

\begin{tabular}{|c|c|c|c|c|c|c|}
\hline & \multicolumn{3}{|c|}{ Shelf life (days) } & \multicolumn{3}{|c|}{$\begin{array}{c}\text { Physiological loss in weight }(\%) \\
\text { pooled }\end{array}$} \\
\hline & 2016 & 2017 & Pooled & 2 days & 4 days & 6 days \\
\hline $\mathbf{V}_{2} \mathbf{P}_{1} \mathbf{W}_{0}$ & 4.00 & 6.00 & 5.00 & 14.57 & 29.38 & 50.54 \\
\hline $\mathbf{V}_{2} \mathbf{P}_{1} \mathbf{W}_{1}$ & 4.00 & 6.00 & 5.00 & 13.03 & 28.38 & 48.32 \\
\hline $\mathbf{V}_{2} \mathbf{P}_{1} \mathbf{W}_{2}$ & 4.33 & 6.00 & 5.17 & 12.32 & 25.84 & 46.40 \\
\hline $\mathbf{V}_{2} \mathbf{P}_{1} \mathbf{W}_{3}$ & 4.67 & 6.00 & 5.34 & 11.66 & 24.58 & 44.85 \\
\hline $\mathbf{V}_{2} \mathbf{P}_{2} \mathbf{W}_{0}$ & 5.00 & 6.00 & 5.50 & 8.41 & 18.87 & 36.39 \\
\hline$\overline{\mathbf{V}_{2} \mathbf{P}_{2} \mathbf{W}_{1}}$ & 5.00 & 6.00 & 5.50 & 7.85 & 14.85 & 34.92 \\
\hline $\mathbf{V}_{2} \mathbf{P}_{2} \mathbf{W}_{2}$ & 3.67 & 5.00 & 4.34 & 7.37 & 12.96 & 33.68 \\
\hline $\mathbf{V}_{2} \mathbf{P}_{2} \mathbf{W}_{3}$ & 3.67 & 5.00 & 4.34 & 6.84 & 7.85 & 20.68 \\
\hline $\mathbf{V}_{2} \mathbf{P}_{\mathbf{3}} \mathbf{W}_{0}$ & 3.67 & 5.00 & 4.34 & 11.18 & 23.74 & 42.62 \\
\hline $\mathbf{V}_{2} \mathbf{P}_{3} \mathbf{W}_{1}$ & 3.67 & 5.00 & 4.34 & 9.74 & 21.97 & 41.25 \\
\hline $\mathbf{V}_{2} \mathbf{P}_{3} \mathbf{W}_{2}$ & 4.00 & 5.00 & 4.50 & 8.96 & 21.25 & 40.55 \\
\hline $\mathbf{V}_{2} \mathbf{P}_{3} \mathbf{W}_{3}$ & 4.00 & 5.33 & 4.67 & 8.62 & 20.75 & 39.34 \\
\hline $\mathbf{V}_{\mathbf{3}} \mathbf{P}_{\mathbf{0}} \mathbf{W}_{\mathbf{0}}$ & 4.00 & 5.33 & 4.67 & 17.55 & 45.28 & 91.86 \\
\hline $\mathbf{V}_{3} \mathbf{P}_{0} \mathbf{W}_{1}$ & 4.00 & 5.33 & 4.67 & 16.57 & 42.53 & 68.42 \\
\hline $\mathbf{V}_{3} P_{0} W_{2}$ & 4.00 & 5.67 & 4.84 & 15.23 & 41.31 & 60.96 \\
\hline $\mathbf{V}_{3} \mathbf{P}_{0} \mathbf{W}_{3}$ & 4.00 & 6.00 & 5.00 & 15.01 & 40.76 & 59.50 \\
\hline $\mathbf{V}_{\mathbf{3}} \mathbf{P}_{\mathbf{1}} \mathbf{W}_{0}$ & 2.00 & 2.33 & 2.17 & 14.81 & 32.74 & 58.01 \\
\hline $\mathbf{V}_{3} \mathbf{P}_{1} \mathbf{W}_{1}$ & 2.00 & 2.33 & 2.17 & 14.28 & 31.62 & 54.51 \\
\hline $\mathbf{V}_{3} \mathbf{P}_{1} \mathbf{W}_{2}$ & 2.00 & 2.67 & 2.34 & 12.50 & 28.80 & 52.28 \\
\hline $\mathbf{V}_{3} \mathbf{P}_{1} \mathbf{W}_{3}$ & 2.00 & 2.67 & 2.34 & 12.17 & 27.42 & 51.64 \\
\hline $\mathbf{V}_{3} \mathbf{P}_{2} \mathbf{W}_{0}$ & 2.00 & 3.33 & 2.67 & 9.24 & 20.59 & 36.49 \\
\hline $\mathbf{V}_{3} \mathbf{P}_{2} \mathbf{W}_{1}$ & 2.00 & 4.00 & 3.00 & 9.02 & 20.11 & 33.66 \\
\hline $\mathbf{V}_{3} P_{2} W_{2}$ & 5.00 & 6.00 & 5.50 & 8.64 & 19.15 & 31.01 \\
\hline $\mathbf{V}_{3} \mathbf{P}_{2} \mathbf{W}_{3}$ & 5.00 & 6.00 & 5.50 & 5.42 & 18.32 & 29.19 \\
\hline $\mathbf{V}_{\mathbf{3}} \mathbf{P}_{\mathbf{3}} \mathbf{W}_{\mathbf{0}}$ & 5.00 & 6.00 & 5.50 & 11.89 & 25.85 & 51.01 \\
\hline $\mathbf{V}_{3} \mathbf{P}_{3} \mathbf{W}_{1}$ & 5.00 & 6.00 & 5.50 & 11.65 & 25.16 & 49.87 \\
\hline $\mathbf{V}_{\mathbf{3}} \mathbf{P}_{\mathbf{3}} \mathbf{W}_{2}$ & 5.33 & 6.00 & 5.67 & 9.82 & 21.75 & 48.53 \\
\hline $\mathbf{V}_{\mathbf{3}} \mathbf{P}_{\mathbf{3}} \mathbf{W}_{\mathbf{3}}$ & 6.00 & 6.33 & 6.17 & 9.48 & 20.97 & 45.48 \\
\hline S. Em ( $( \pm)$ & 0.18 & 0.30 & 0.18 & 0.23 & 0.33 & 0.58 \\
\hline $\begin{array}{c}\mathrm{CD} \\
(\mathrm{P}=\mathbf{0 . 0 5})\end{array}$ & 0.52 & 0.86 & 0.50 & 0.65 & 0.92 & 1.61 \\
\hline
\end{tabular}

*Treatment details refer to material and methods 
Fig.1 Individual effect of varieties on physiological loss in weight after 4 days (\%)

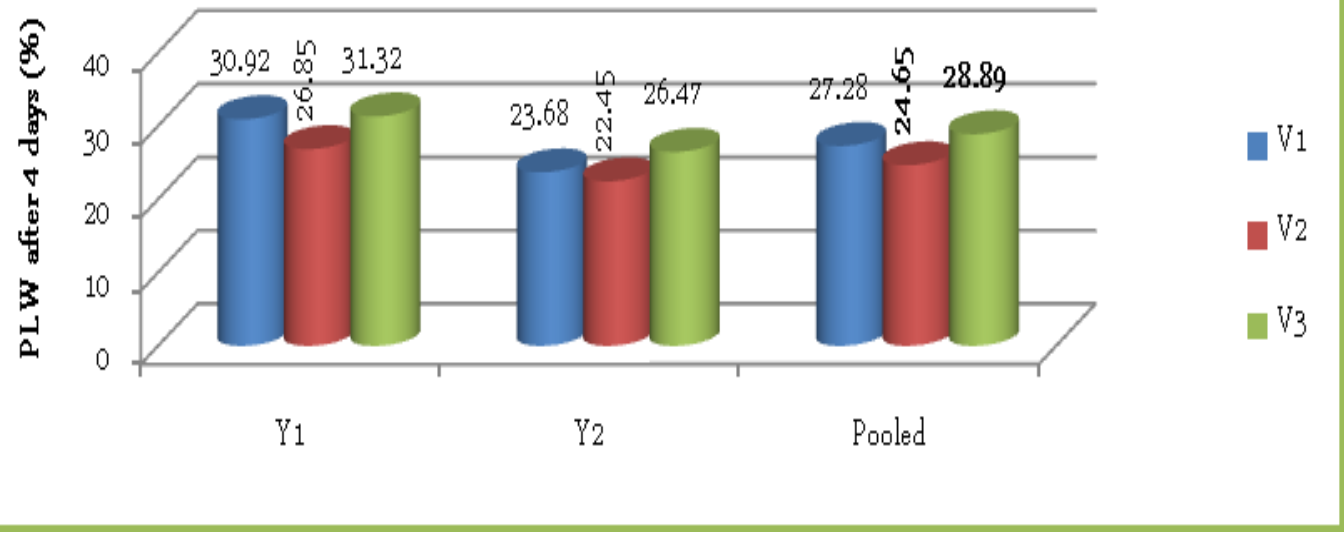

Fig.2 Individual effect of panchagavya on physiological loss in weight after 4 days (\%)

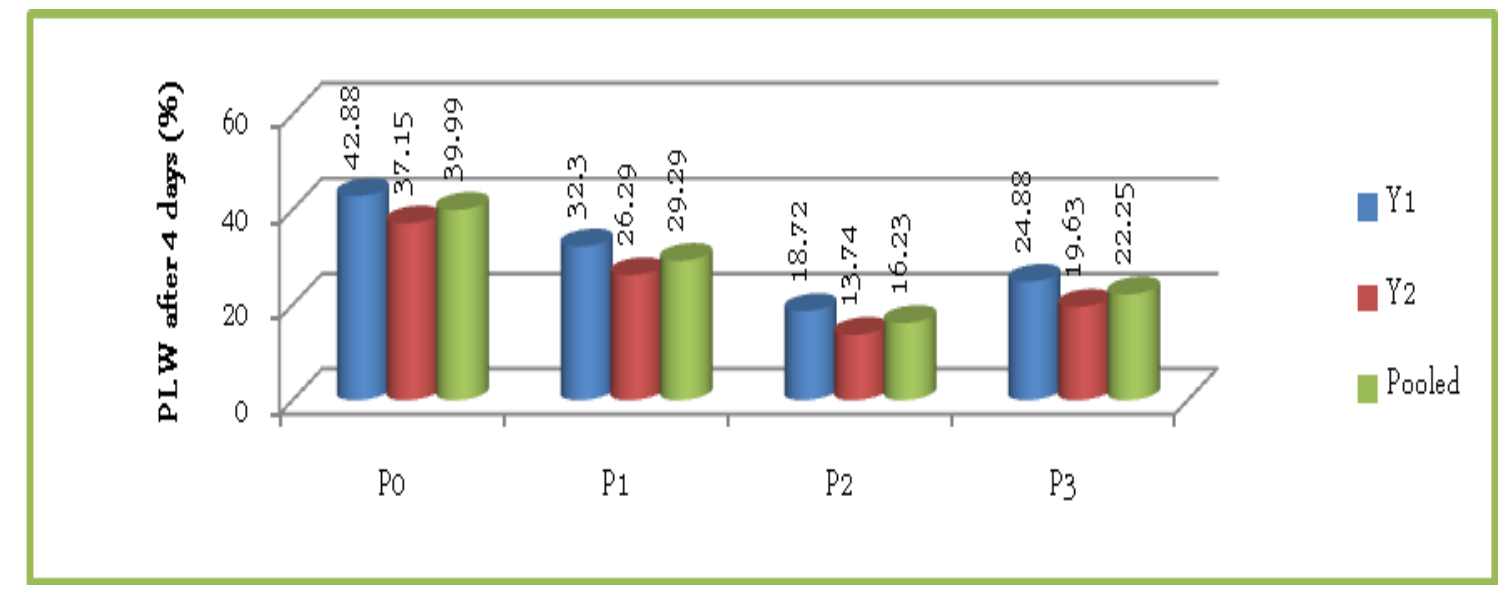

Fig.3 Individual effect of vermiwash on physiological loss in weight after 4 days (\%)

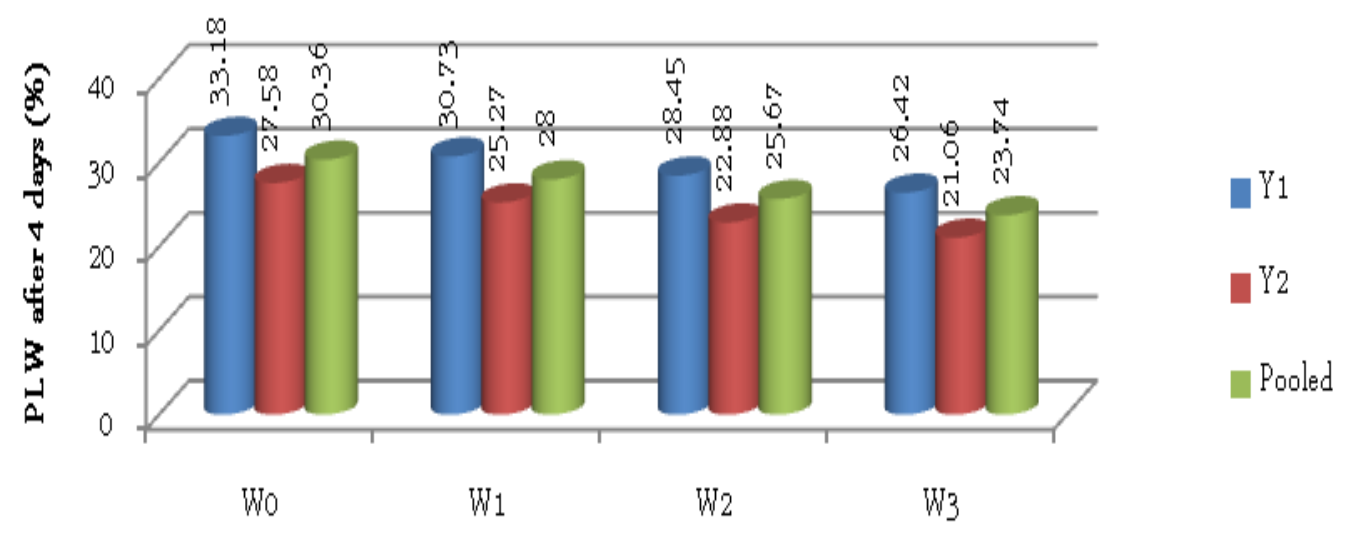




\section{Int.J.Curr.Microbiol.App.Sci (2018) 7(10): 1427-1434}

Fig.4 Interaction effect of varieties, panchagavya and vermiwash on physiological loss in weight after 4 days (\%)

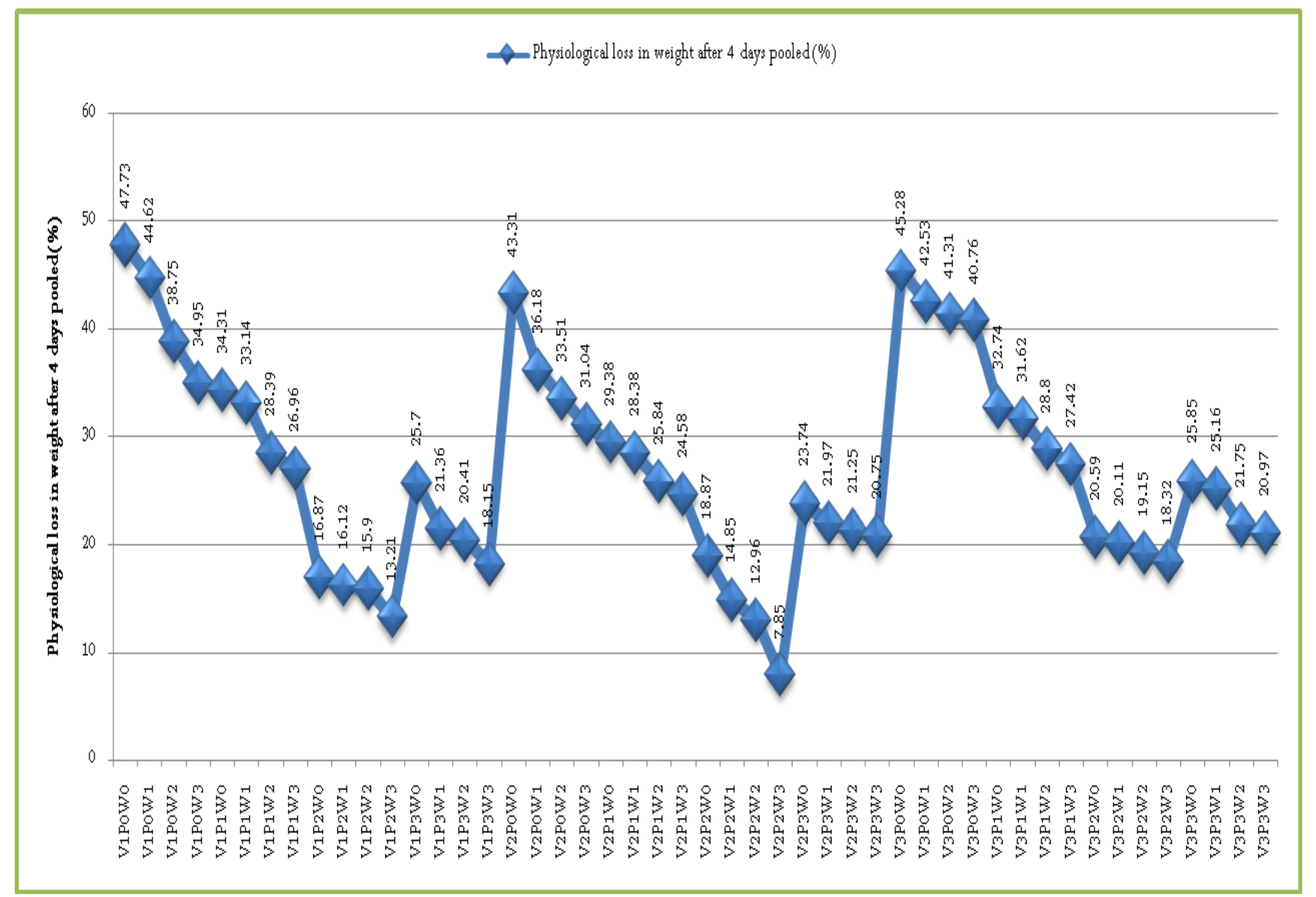


The maximum shelf life (3.58 days and 4.75 days in 2016 and 2017, respectively and 4.17 days in pooled analysis) of bitter gourd was recorded in $\mathrm{W}_{3}$ treatment (vermiwash $10 \%$ at 25, 50 and 75 DAS). The interaction effect of variety, panchagavya and vermiwash on shelf life of bitter gourd was found to be significant for both the years and in pooled analysis. The maximum shelf life (6.00 days and 6.33 days in 2016 and 2017, respectively and 6.17 days in pooled analysis) of bitter gourd was recorded in $\mathrm{V}_{3} \mathrm{P}_{3} \mathrm{~W}_{3}$ treatment (Gangajal-1, panchagavya $3 \%$ at 20,40 and 60 DAS, vermiwash $10 \%$ at 25,50 and 75 DAS). The minimum shelf life (1.00 days and 2.00 days in 2016 and 2017, respectively and 1.50 days in pooled analysis) was recorded in $\mathrm{V}_{1} \mathrm{P}_{0} \mathrm{~W}_{0}$ treatment (Peyarafuli Ucche, control, water spray). As the liquid organic manures has the properties of increasing storage quality which might have enhanced the shelf life of bitter gourd fruits by foliar application of liquid organic manures.

The physiological loss in weight (Table 1 and 1a) is also an important storage parameter of bitter gourd. Figure 1-4 shows the physiological loss in weight after 4 days of storage of bitter gourd fruits. Among the number of sprays of panchagavya the treatment $\mathrm{P}_{2}$ (panchagavya $3 \%$ at 30 and 60 DAS) recorded lowest physiological loss in weight after 2, 4 and 6 days (10.12\%, $5.58 \%$ and $7.85 \% ; 18.72 \%, 13.74 \%$ and $16.23 \%$; $32.86 \%, 28.28 \%$ and $30.57 \%$ ) in both the years and pooled analysis respectively. Similar observation was recorded earlier by Ravichandran et al., (2011) in potato. Among the number of sprays of vermiwash the treatment $\mathrm{W}_{3}$ (vermiwash $10 \%$ at 25,50 and 75 DAS) recorded lowest physiological loss in weight after 2, 4 and 6 days (13.24\%, 8.43 $\%$ and $10.83 \% ; 26.42 \%, 21.06 \%$ and 23.74 $\% ; 45.93 \%, 39.66 \%$ and $42.79 \%$ ) in both the years and pooled analysis respectively. Whereas, among the interaction the $\mathrm{V}_{2} \mathrm{P}_{2} \mathrm{~W}_{3}$ treatment (Pundibari Local, panchagavya 3\% at 30 and 60 DAS, vermiwash $10 \%$ at 25,50 and 75 DAS) recorded lowest values for physiological loss in weight after 4 and 6 days of storage $(9.80 \%, 5.90 \%$ and $7.85 \% ; 22.48$ $\%, 18.88 \%$ and $20.68 \%$ ) in both the years and pooled analysis respectively. The increase in physiological loss in weight after 6 days of storage was due to loss of moisture from the fruits and also due to increased rate of respiration, transpiration and active physiological processes.

\section{Acknowledgements}

Authors are thankful to the technical and financial support from the University, Uttar Banga Krishi Viswavidyalaya (UBKV).

\section{References}

Beaulah, A. 2002. Growth and development of moringa (Moringa oleifera L.) under organic and inorganic systems of culture. Ph.D. Thesis, Tamil Nadu Agricultural University, Coimbatore.

Dutta, P.K., A. K. Chakravarty, U. S. Chowdhury and S. C. Pakrashi. 1981. Vicine, a Favism inducing toxin from Momordica charantia Linn. Seeds. Indian J Chem. 20: 669-671.

Fisher, S.R.A., and Yates, F. 1963. Statistical tables for biology, agricultural and medical research. $6^{\text {th }}$ edition. Oliver and Boyd. Edinburgh Tweedale Court, London.

Grover, J.K., S. Yadav and Vats, V. 2002. Medicinal plants of India with antidiabetic potential. J Ethnopharmacol. 81: 81-100.

Panse, V.G., and Sukhatme, P.V. 1985. Statistical methods for agricultural workers. Indian Council for Agricultural research (ICAR), New Delhi, India, 
Rajasree, G., and Pillai, G.R. 2012. Effect of nitrogen nutrition on fruit quality and shelf life of cucurbitaceous vegetable bitter gourd. J Plant Nutr. 35: 11391153 ,

Ravichandran, G., N. Natarajan, K. Manorama and Vanangamudi, K. 2011. Effect of organic sprays on storage behaviour of seed potatoes. Indian $J$ Hortic. 68(3): 399-407.

Smoleń, S. 2012. Foliar Nutrition: Current State of Knowledge and Opportunities. In: A. K. Srivastava (Ed.). Adv in Citrus
Nutr. Springer Science + Business Media, pp. 41-58.

Subba Rao, A.K., Sammi Reddy and P. Ramesh. 2007. Protecting soil health under conventional agriculture and organic farming. Green Farming. 1(1): 1-9.

Yeh, G.Y., D. M. Eisenber, T. J. Kaptchuk and R. S. Phillips. 2003. Systematic review of herbs and dietary supplements for glycemic control in diabetes. Diabetes Care. 26: 1277-1294.

\section{How to cite this article:}

Somashekar Gajjela, Ranjit Chatterjee, Sushmita Subba and Eggadi Ramesh. 2018. Studies on Storage Behaviour of Bitter Gourd as Influenced by Liquid Organic Manures. Int.J.Curr.Microbiol.App.Sci. 7(10): 1427-1434. doi: https://doi.org/10.20546/ijcmas.2018.710.158 